\title{
SYMBOLISM AND RITUAL AMONG THE AKAWAIO OF BRITISH GUIANA
}

For the purpose of this article it is convenient to keep in mind the following definitions (cf. The Concise Oxford Dictionary): A ritual: is "a ceremonial act, observance or procedure".

A symbol: is "a thing regarded by general consent as naturally typifying or representing, or recalling something by possession of analogous qualities or by association in fact or thought".

I should like to stress the first part of the definition of a symbol - namely that it is a thing so regarded by general consent. I am only prepared to regard the meaning of an action or thing as it is expressed by the people themselves, or as it can be found unmistakably implied in the social context. What I particularly wish to avoid is the imposition of preconceived ideas from another society with a very different system of thought for it is not profitable to confuse the meaning which the people give with the meaning which the observer ascribes to an act or thought. The meaning which the people give will contain the symbolism, if there is any; the meaning which derives from the observer will give, at the best, the social significance: at the worst it will give the observer's own thoughts.

Interpretations are subject to frequent changes; moreover, we have all encountered books containing elaborate systems of symbolism which have been foisted by their inventors on some obscure rituals of primitive peoples. Rarely do such revelations of symbolic meanings ring true and the reader is left with the feeling that more is owed to the ingenuity and labyrinthine

The author, who is Demonstrator and Lecturer in Ethnology at the Pitt Rivers Museum, Oxford, carried out field research among the Akawaio Indians of British Guiana in $195 \mathrm{I}-52$ and in 1957 . She acknowledges with gratitude financial aid and equipment received from the Colonial Development and Welfare Corporation, the American Association of University Women, the University of Oxford and the London University Central Research Fund. 


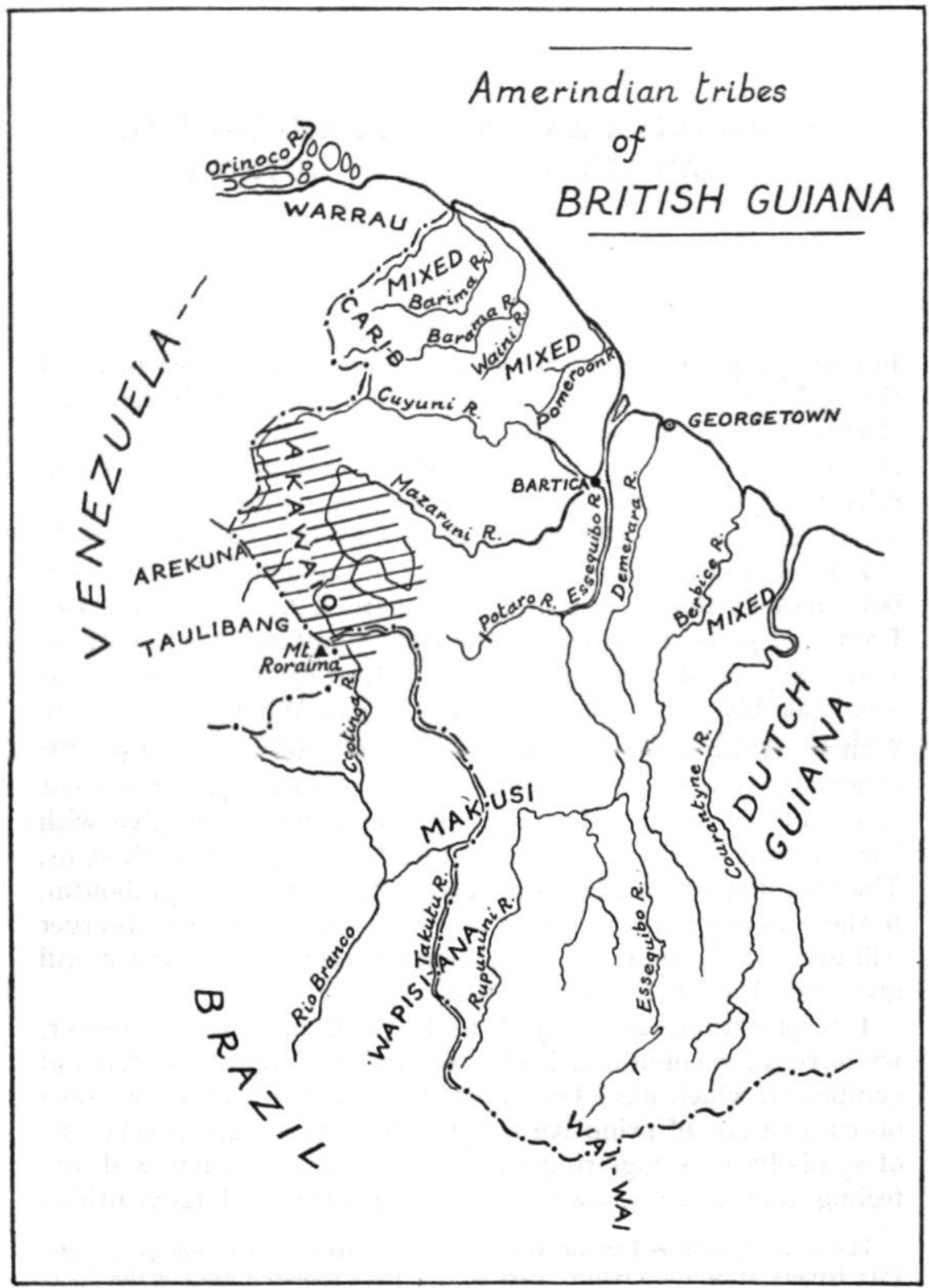

Fig. I. Sketch map of British Guiana with Akawaio territory striped. 
complexity of the author's brain, or to the school of thought he was trained in, than to an understanding of those who performed the original actions. Certainly in the case of the Guiana literature, the interpretations and guesses which various authors have hazarded, based on insufficient knowledge of the language and people, rarely have more than the palest resemblance to the actuality as expressed by the people themselves - and necessarily, the conclusions drawn from these inaccurate interpretations are open to doubt.

Even more important is the fact that the statements made by observers are not anywhere near as interesting or productive of thought as those made by the Amerindians themselves.

The main difficulty in presenting an account of Akawaio symbolic behaviour and related beliefs is what to leave out. It is no exaggeration to state that Akawaio conceptions are riddled with symbolism; moreover, it is a symbolism which can easily be recognised as such once a certain competence in the language has been attained. Here, I select some particular rituals and discuss the symbolism contained in them in the confident belief that what I describe is fairly typical of what has had to be omitted.

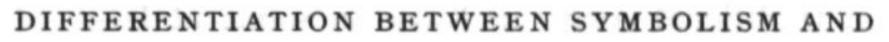

First, I wish to differentiate briefly between symbolism and other forms, such as simile and analogy, because this will lead to a better understanding of Akawaio conceptions of thought in general.

I) The Akawaio are very fond of playing about with words. For example, they often amuse themselves with word games when lying in their hammocks at night before going to sleep. One will think of a word or person's name, reverse it or otherwise mix up the syllables and the others will try and guess what the proper word is.

Akawaio also have a feeling for the sound of words, but at the same time, in making up a word, forming new combinations or adapting a word, they like both to be appropriate and also to give the word an expressive meaning. This usually takes the form of creating a word picture or making the word refer to some characteristic. They are exceptionally able at making up nicknames.

2) Very frequently the Akawaio convert their words into si- 
miles. They have a good number of suffixes which enable them to do this. Amongst the most usual ones are the ending '- $k a s a$ ', meaning 'like'; '-warai', meaning 'similar to', while any noun can have '- $b e$ ' tacked on to the end. This suffix '- $b e$ ' can give all sorts of twists of meaning to a word. It can make a noun into an adjective; e.g. ' $n o p u$ ' = wife; ' $n o p u b e$ ' = wifely; or it can be used as a straight simile, i.e. 'nopube' meaning 'like a wife' (but implying that she is not one in fact); or it can be used to give a meaning of status or position, as 'nopube' meaning 'stands in the position of a wife' (implying in this case that she actually is one). In this latter usage it can be interchangeable with the noun without the suffix. I found Akawaio more flexible and expressive, if more vague, than English in this use of '-be' and it is no good trying to translate it with a straight English adjective on every occasion.

If the Akawaio come across anything unfamiliar their first reaction, like most peoples perhaps, is to liken it to something which is familiar to them, and they do so in ordinary speech by using the suffixes I have mentioned.

3) Nearer to symbolism is the simile which has turned into an allegory. This occurs chiefly in the poetic picture language used in traditional songs, and also in some, at least, of their folk-lore. Very many of the old songs appear at first sight to be simple descriptions of scenes from nature. Sometimes they are obscure enough to be practically incomprehensible to anyone who has not a very intimate knowledge of the creatures which live in the Guiana countryside.

E. g. "Like fish darting to take flowers dropping on the water"-meaning that people are coming eagerly to drink cassiri ${ }^{1}$ from the hollowed out tree trunk.

E. g. "Aiari ${ }^{2}$ comes from the mountain and stupifies fish" - meaning that the drinks at the spree are strong like the aiari and are going to stupify the people; i.e. make them drunk.

E. g. "The Nakoko bird sits on a tree over a big river" - meaning: just like the Nakoko bird so the people at the beginning of a spree sit and wait over the flood of drink prepared for them.

E. g. "The Duckler is swimming round and round on the river" - meaning : like this bird the singers are dancing round and round in the house.

These are all songs sung at the 'spree', the Indian celebration of feasting, dancing and drinking. Very occasionally, the suffix '- $b e$ ', meaning 'like' in this context, occurs at the beginning of

1 A fermented drink made from cassava and purple potatoes.

2 Tephrosia toxicaria, used to poison the rivers at times of low water in order to obtain fish. 
the description, but apart from this there is often nothing to indicate the true meaning of the allegory - either in word or accompanying action. Had I not been lucky enough to encounter an Akawaio who volunteered the true meaning, quite by chance, I might have gone on asserting, like other travellers, that the people merely sing about the birds and animals, for to ask for a meaning presupposes knowledge of the fact that there is more than meets the eye, and I had thought the songs quite obvious. "Not real birds", said my informant hesitatingly, "not real fish - but just like them". Then he added, "it means people".

Once the anthropologist becomes accustomed to this way of thought and the type of analogy, he can soon see many of the meanings before asking for explanation.

$$
\text { SYMBOLISM IN 'TALING' }
$$

Let us proceed from near symbolism to symbolism in the sense of the definition I have adopted. My first example is that which is involved in 'ritual blowing', or taling. I choose this aspect of Akawaio beliefs because it continues onto a symbolic plane of thought their tendency of giving a word picture and also because taling is essentially a ritual procedure.

Detailed information on ritual blowing has already been published (I) but during a period of further field research in 1957 I obtained additional information which throws more light on the thought processes behind the ritual.

Ritual blowing is a process whereby an Akawaio can cause an enemy to fall sick and perhaps die, or whereby he can help a friend or relative to recover from sickness. It can also be used for success in hunting, to keep away rain, to prevent or induce pregnancy, to cause an easy birth, to make the garden prosperous in fact, it can be used to achieve almost any end, good or bad.

People blow by forcing their breath through the mouth in short, sharp gusts; at the same time the blower has to utter certain words under his breath. These are the two essential acts, though sometimes tobacco smoke is used as an aid and it is also believed that, by and large, old people know best how to blow effectively. When a person blows the Akawaio believe that his or her spirit or vitality (akwalu) goes out from the body and performs the work. In these beliefs, spirit and breath are frequently associated. In addition, and this is a fact I did not know when I first wrote about taling, the words which are muttered invoke an outside spirit helper. 
The following taling words are supposed to cure engup, an eye infection caused by a small fly - according to medical, but not Akawaio, opinion!

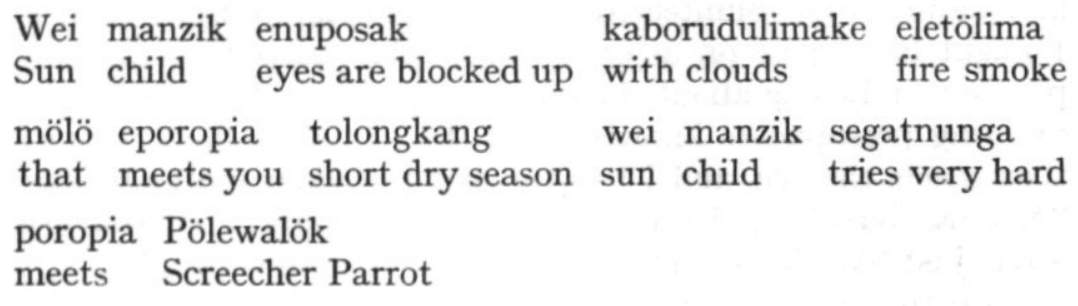

Blows :

To make a word for word translation, without assistance, was impossible. This is because the words used are frequently those which never occur in ordinary speech. Manzik, for example, is never used except in taling. The normal Akawaio word for 'child' is mule,

The explanation which was volunteered is as follows: - "The sun child used to be a person", they said. (This refers to the culture heroes of these Carib tribes, brothers who were born of the sun and a woman on earth.) "People's eyes get blocked up with smoke clouds from the fire". (This gives them engup eye infection sometimes.) "In the same way, in the short dry season, smoke from garden fires blocks out the sun child's eyes." (This refers to the fact that people burn their newly cut gardens in the short dry season when the felled vegetation is withered and burns easily. Very often, the people of a village burn several gardens in one day and as you stand in the village columns of smoke from distant clearings rise above the forest and block out the sunshine.) In other words, just as people's eyes get 'blocked up', or swollen, with fire smoke, so the sunshine is blocked out when gardens are burnt in the short dry season. It is interesting to note that 'sunshine' in Akawaio is literally 'the sun's eye' (wei уепu).

To cure the eye trouble the parrot spirit is invoked. The explanation given was "the parrot meets the patient and tries very hard to cure the illness with his own wind. That is" my informants added, "the parrot flying across the sky makes a way through the smoke clouds and seems to be trying to clear the clouds away".

What the taling words do is to create a picture, of smoke clouds 
over the forest blocking out the sunshine. A flock of parrots, disturbed by the fires, flies away through the smoke and as they go they seem to be clearing a pathway through it and letting the sunshine filter through: - so the parrot spirit is invoked to clear the eyes of the patient which are believed to have suffered from fire smoke in the house at night or when cooking.

Another example of blowing words to cure the same eye infection is as follows: "Creek water in a big pool has rubbish, leaves, dead flowers, seeds etc., floating on top, these have blocked the eyes of the swimmer. Someone tries to clean out the eyes but they cannot. Eyes are like pools - they have engup on top, or in other words, rubbish, as pools and creeks have. The duck can clear a way through rubbish when swimming so the duck helper, when called on with the right words, can get the person clear eyes".

Whooping cough in Akawaio is called arowdaima. Arowda is the howler monkey and so it is, literally, 'howler monkey sickness'. To cure this the Akawaio blowing words call on the chicken hawk and the eagle. They say the various monkeys, the birds, the sloths and all the creatures which live in the tree tops are scratching the tree with their claws and spoiling the tree's voice and making the tree cough. The eagle and chicken hawk are summoned as helpers because they swoop down and eat the tree-top animals and birds: - so these helpers will cure the person who has howler monkey sickness and whose voice has been spoilt by it, for the birds invoked will destroy the causes of the illness.

One rather amusing blowing ritual is to stop thunder and rain. The words say that the forest spirit, Imawali, gets angry; so do all the mountain spirits and the mountain snakes. "When they are angry they make thunder and rain steady", said an informant, "so the owner of taling calls on the electric eel because it will stop the angry spirits from making thunder and rain by giving them all an electric shock".

Taling, or blowing, is a ritual procedure, being ceremonial, and the Akawaio themselves regard it as being quite different from ordinary breathing or puffing of the breath. They have different words for the two actions. It is noticeable that the similes and allegories used are mostly taken from the natural surroundings of the people and sometimes, from social life. The same can be said for their symbolism: - the taling words, like the spree songs create a word picture of a scene in nature. The Akawaio think 
in terms of natural symbols, rather than in terms of conventional symbols by which signs have been arbitrarily chosen and stand for things or ideas with which they have nothing in common except association in thought. This habit of creating word pictures of natural scenes makes their spree songs and blowing words look deceptively alike. However, there is a difference. The spree song picture, as e.g. the duckler swimming round and round, is just a plain narrative description by which one subject (usually social, as dancing round and round), is described in the guise of another which is suggestively similar. That is, it is an allegory, as already mentioned. The taling word picture, on the other hand, is deliberately employed because analagous qualities are represented in it and, by virtue of these qualities of resemblance, there is thought to be an actual association between the pictures or thought which is called to mind and the social reality which the Akawaio is trying to affect. There is believed to be present an affective relationship and this makes the picture employed a symbolic one and not just poetic description. Moreover, something is supposed to be achieved by this use of association of qualities of resemblance. This appears to me to be the essence of Akawaio categories of symbolic thought and it is fully covered by the definition which is stated at the beginning of this article.

So far, I hope to have shown that in the case of the Akawaio practice of blowing to attain their wishes, there is a very close association of a symbolic mode of thought and a ritual method of procedure. The details given serve to show exactly how the two are associated and the effect they are thought to have according to the beliefs of those who engage in the ritual. If I were to analyse every aspect of the ritual there would be other factors besides symbolism to take into consideration. According to the Akawaio shaman, who claims to be able to see spirits during his seances, a person who is sick from blowing has three spirits in his body. One is the sick man's own spirit which normally resides within him and has nothing to do with the blowing ritual which has been practised against him. A second spirit is that of the person who blew the sickness, which went out with his breath and entered the victim in order to work the intended evil. A third spirit is that of the nature spirit which the blower summoned to his aid by pronouncing certain words and evoking the power of symbolic association.

In terms of the older schools of anthropological theory this spirit activity would come under the heading of animistic religion, 
whereas the mode of summoning the spirit helper and the effects achieved by the symbolic association involved would be regarded as magic and witchcraft. Although I am only considering the symbolic aspects of the ritual in this context it is important to note that spirit beliefs are involved which appear to stem from quite a different line of thought from the symbolic one. To lump everything under the term of 'ritual' is such a convenient habit because it saves anthropologists the trouble of dealing with the vexed question of differentiating between religion and magic. On the other hand, it may well have the result of obscuring some very different elements and processes of thought - of which symbolism may be only one.

\section{SYMBOLISM AND CHARMS}

\section{Tattooing}

One of the most noticeable features of many Akawaio women is the characteristic pattern of tattooing on the lower half of the face, in the region of the chin and mouth. There is also some tattooing on the limbs, particularly the forearms. The patterns are achieved by cutting or pricking the skin and rubbing in a black dye. The ingredients of the dye used are always two kinds: something black and something sweet. Lamp black mixed with burnt sugar cane or wild honey are most usual. The patterns themselves are various. Some typical ones are shown in Fig. 2.

One common arm pattern is called the 'fish skin pattern' and I learnt that this particular fish, the hassar, has a skin which tastes sweet. Another one is tedzang, which is the name of a honey bee. Another pattern represents the spider and yet another, the camudi snake - the big Boa constrictor which we see depicted on the covers of South American travel books in an attitude of being about to squeeze and gobble up the intrepid explorer, his canoes and retinue. The kansök pattern is the scorpion's tail. Years ago the women cut their tongues and rubbed in honey or the juice of a sweet tree bark.

The women regard all these patterns as cooking charms, using the word murang which I discuss later on. With these charms they can make sweet cassava bread (the staple food derived from manioc) and also sweet drinks. A girl receives her first tattoo patterns, usually on the arms, some years before puberty and I once saw a number of little girls lined up for the operation with an age range from 6 to I2 years. One girl had already had 
several patterns. The scorpion's tail pattern on the face, is also a sign of puberty and the process of tattooing it is usually reserved until then. Women may continue to add tattoo patterns from time to time after puberty and even after several years of marriage.
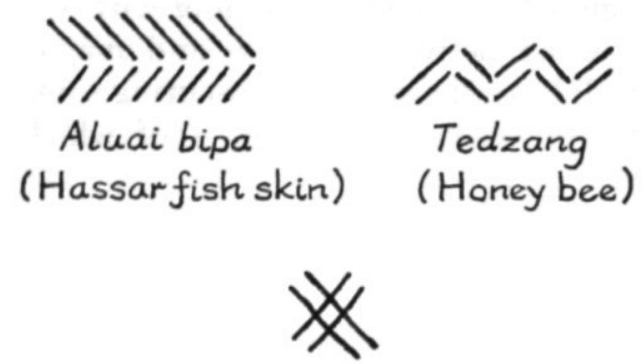

Arai

(Spider)

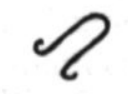

Kansök

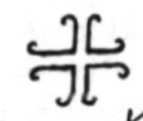

Kansök

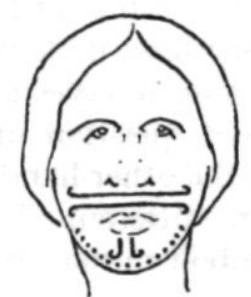

Kansök pattern (Scorpion's tail)

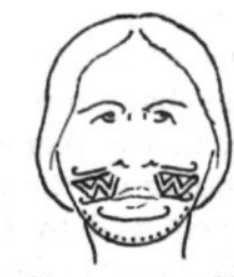

Kansök pattern

\& camudi snake.

Fig. 2. Some typical patterns of tattooing among Akawaio women.

A study of tattoo patterns leads to the realization of an extensive form of symbolism underlying their execution. Why, we may first ask, should stress be laid on sweet cassava and sweet drinks? The answer lies in the methods of brewing and the type of occasion for which drinks are required. Most of the traditional Akawaio brews derive from garden products such as yams, cassava, potatoes and maize. The most notorious incident in brewing is that involving the chewing of part of the ingredients of the drink and spitting the chewed food back into the drink which is then left to ferment. One of the classic incidents in books published on British Guiana Indians is that in which the author describes how he drank certain brews and then found out to his dismay how they were made, and what his reactions immediately were!

The function of chewing is to assist the fermentation and give a better taste. The saliva acts on the starchy substances and a 
chemical change occurs converting the starch into sugar. The sugar, after a short lapse of time, produces a stronger, fermented drink than would otherwise be obtained. Nowadays, chewing is rarely done and sugar cane juice is used instead. However, sugar cane is not indigenous to South America and though it was adopted enthusiastically by the Indians its use as a brewing aid replacing chewing does not appear to have come into vogue among the Akawaio until this century.

Alcoholic drinks are important for Akawaio celebrations for they get everyone into a jolly mood (sometimes a quarrelsome one), and create the party atmosphere which alcohol does with us. They also provide the means of enjoyment for various minor social occasions, at communal meals, family parties, visits, working parties, and so forth. The drink is as much a food as a drink on account of the sugar content and stimulant and it is an invaluable pick-me-up on long journeys and during periods of hard work. Consequently, it is easy to see, in virtue of the importance of alcoholic drink in the society and its mode of preparation, why stress is laid on sweetness. The women, who did nearly all the chewing before sugar cane was used and who bake the cassava bread and prepare the drinks, bear the symbols of sweetness, and of the bee in particular - the insect which produces the essence of sweetness. The tattooed arms prepared the drink and the tattooed mouth and jaw chewed to produce the sweetness. Among the Barama River Caribs of British Guiana, we are told that a woman could only pass a drink to a man if her arm was tattooed. (2)

Less obvious is the symbolism of the spider, scorpion's tail and snake patterns, seen tattooed across the cheeks of elderly Akawaio women. The explanation from the Akawaio viewpoint was given me as follows: "Women have the scorpion's tail patterns in order to make sweet cassava and drinks. They also have the symbols of bees and other things on their arms, as well as the scorpion's tail on their arms and round their mouths. Years ago, bees with painful stings were represented. This is because the women wanted to be able to make sweet, strong cassiri and other drinks which would get the people drunk at sprees".

The sting in the scorpion's tail, the sting of bees, the sting of the ant and the bite of the spider and camudi snake are symbols which Akawaio have taken from nature and which they use to help them to produce a strong drink with a kick - or sting - in it. (3)

The patterns have an aesthetic as well as a practical appeal 
to the Indian. They are regarded as beautiful, or were so regarded in the past; they attract the opposite sex and are a mark of maturity and of the attainment of certain skills, namely cooking and brewing. On the practical side they are believed to assist the bearers of the patterns in these specific skills. The aim of the women is to produce a powerful drink to make the men merry and drunk during celebrations and to achieve this they enlist the aid of the creatures which possess the necessary characteristics and by symbolic association they think to reproduce these same qualities.

Tattooing is what is called an urichang murano, that is, a 'woman's charm'. A few men also have some tattoo marks round the mouth in the scorpion's tail pattern, but the ingredients of the dye differ, being a compound of charred plant roots. These warawok murano, that is, 'men's charms', are hunting charms. These, I now wish to discuss.

\section{Hunting \& Fishing Charms}

Hunting and fishing charms are various:

I) The most common is the plant variety. Special charm plants are grown round the settlements and in the gardens. A piece of the root of one of the plants is dug up and the man's chest or arm is cut in several places, so that the blood flows; then the root is dipped in water and the juice squeezed from it into the cuts.

2) Sometimes a latticework is made and ants placed between the slats. The stinging side of this ant frame is then pressed against the flesh of the hunter, his arms or chest, so he gets badly stung.

3) Juice from frogs is frequently rubbed into cuts on the arms and chest in the same way as juice from plant roots.

As with other procedures which are inspired by a symbolic way of thinking it is at first sight difficult to make any sense of this type of charm. Most observers, ethnologists and psychologists, have said that they are a form of self-torture before hunting and that they have the effect of training the Indians to endure pain. One psychologist maintained that the conscious reasoning behind them is to ensure alertness for the hunt. Maybe they do have these effects but the Akawaio just roared with laughter at these explanations for they use the charms with quite a different purpose in mind.

Let us consider the leaf charms first: often they are caladiums, with splashes of white, cream, pink or red on the leaves. Some- 
times, various lilies, as the red Amazon lily, are used; sometimes reeds or grasses and sometimes yet other plants. Each animal has its own plant charm, so that if you want to hunt tapir you take the tapir charm plant; if you want powis (crested curassow) you take the powis charm plant, and so on.

"How do you know these plants will get you meat"? I asked various Akawaio. Sometimes they replied by saying that they got the plants from old time people and knew from experience that they were good for hunting: more often they began to give other explanations. The caladium with cream splashes on its leaves proved to be reminiscent of the markings on young tapirs. A deer charm had a large green-purple leaf, like a deer's heart. Another had cream veins, like the stripes which young deer have. A yarrow fish charm had a leaf shaped like a fish's liver. A wild turkey charm was a caladium with red veins in the centre and white spots - the bird has a red wattle and white flecks on its breast. Yet another caladium had a leaf like the head and ears of an aguti while the red spots were said to be like the bête rouge ${ }^{1}$ on its nose. One leaf was reminiscent of the weluwe, a fly. If the root is grated and put on a dog's nose then the dog hunts everything and rushes about after meat - just like the weluwe fly!

The ant frame has a similar mode of thought governing its use. Ants are energetic hunters, going out early in the morning to seek food - so must the hunter be energetic and get up early. One type of ant is an aguti charm because the ants are the same colour as this rodent.

Frog charms are used and in some instances the connection between the frog and a certain animal is explained in folk-lore. However, the kunawa frog (Phyllomedusa bicolor) ${ }^{2}$ is used as a charm because this tree frog has its home in a small pool of water in a tree and the pool is usually filled with all sorts of feathers of different birds. This, for the Akawaio, indicates that the kunawa frog attracts birds to it.

How are the charms believed to work? The caladium roots, which constitute a large section of the charms, are said to make your skin itch. The itching in the hunter's skin draws the itching animal to him. It is true of all hunting and fishing charms that they are believed to call the animals and fish to those who have

1 Bête rouge = Trombidium sp., is a minute red insect which burrows into the skin and causes much irritation.

2 My thanks are due to Mr. Woodsey of the Oxford University Potaro River Expedition of 1959 for this identification. 
taken the charms. Since Akawaio techniques are based mainly on stalking game through the forest, imitating their calls and bringing the creatures within easy reach of a shot with bow and arrow, gun or blow pipe, we can see how appropriate these charms are. That hunting techniques have a definite connection is also suggested by the fact that one type of peccary is said not to have a charm, because it is got by tracking and not by calling.

The word murang, which I translate as 'charm', is applied to all charms which I have described. Its literal meaning is 'attraction' and the verb, muranguya, means 'I attract'; the object of the murang is to attract meat, fish, etc., by reason of the symbolic association which is perceived between it and the creature it resembles in some way.

There are other murang, or charms, besides the hunting and fishing ones and the cooking and brewing charms in the women's tattoo patterns. There are charms for making people energetic workers, for making women's hair grow long; making people plump; enabling the shaman to bring down certain spirits during his seance; making someone love you; making children grow tall; enabling you to sing well, and to achieve many other things. To give one detailed example out of all these: the shaman (piai' chang) squashes the wamong (sun bee) and drinks it in water because this insect makes your voice "come good". "The bee has a loud voice", and in fact one can always tell a shaman who has taken this charm because when he sings a spirit song during a seance there is a characteristic ringing noise in the last longdrawn out note, reminding one of the sun bee and the loud whirring noise it makes in the forest at dawn and sunset.

Medicines among the Akawaio are frequently referred to as murang, or charms, although there is also another word, dibik, meaning a 'cure', (dibikuya = I cure) which is applied specifically and corresponds more to our word 'medicine'. There is a great deal of interchangeability in the use of murang and dibik, both as regards the hunting charms I have already described and the charms designed to cure sickness. This interchangeability is understandable if we examine the various types of medicines in vogue among the Akawaio.

\section{Medicine Charms}

Some medicines are plants which are administered in the same way as hunting charms - i.e., by cutting the skin on arms and legs and rubbing in juice from a plant root. Sometimes infusions 
are drunk, made from bark, leaves or roots of a plant or tree. Sometimes ant frames are administered.

Even more indicative of the essential similarity between 'charms' and 'cures' is the symbolic way of thinking which is at the base of them both. Just as with hunting and other charms the efficacy of medicines is usually based on some form of symbolism. Generally, however, the form of the association between the medicine and the illness to be cured, is rather different from that which is most common between the hunting charm and its animal. For example:

I) A cure for the eye infection (engup) is Piait'ma manadu. It is a fungus which grows on rotten branches which litter the forest floor. The name of the cure means 'Piait'ma's breast'. Piait'ma is an order of mountain spirits and the breasts of Piait'ma women are long and flapping. When the shaman brings down a Piait'ma spirit during his seance she is said to carry cooling medicine in her breasts to cure the patient. The fungus which bears her name is shaped like a long breast and has a white juice inside. The patient nips off the end of the fungus and squeezes this juice into his infected eye and so his sickness will be 'cooled down'.

2) Piait'ma mömbödöpö - literally meaning 'Piait'ma's afterbirth', is a particularly nasty looking clay which is found on the banks of rivers. If a child is sick with bronchitis or has a very bad cold, the clay is mixed with water and the person bathed in it. This too, cools down the sickness. As one informant aptly remarked "Piait'ma is a good cooler"!

3) Dew is collected and drunk for a cold. Dew is called chilikö itagu - star spittle. Water is cool from the stars and therefore cools down sickness. Immersion in cold water, in a river, is another method of cooling down sickness.

4) Just as a range of 'cooling down medicine' is used as cures so another set - of bitter medicines - is used in medical treatment. Seeds, infusions of leaves and hot things like pepper and ginger, are all used to drive off the sickness from the patient. Bitter things are believed to stop blood from flowing, so there is a whole range of bitter medicines used by menstruating women.

This idea of the properties or essence of substances is clearer still in certain ritual occasions into which this particular way of thinking enters most strongly. 


\section{Puberty Rites of Girls}

At the time of first menstruation a girl is slung in her hammock away from the men who would have no success in hunting if they had contact with her - so it is believed. Often she is partitioned off with leaves of the purple heart (Peltogyne sp.) or green heart (Ocotea rodiaei) trees. The girl may be given the ant frame to make her an energetic and good worker, like the ants.

The Akawaio believe that bitter things prevent the flow of blood, or at least lessen it. Hence the use of the purple heart partition, for the leaves are bitter. A medicine used for the same purpose is made of the bitter fruit of the green heart tree. At about the same time the girl's mouth used to be tattooed with the scorpion's tail pattern. It is noticeable that although these observances come together and are marked out as a particularly obvious ritual at time of puberty, they are also carried out, in a less obvious and in piecemeal fashion, at other times. For example, women, especially girls, may take leaf charms or ant frames to enable them to work hard at any time before or after puberty. Bitter medicines are used to lessen the flow of blood at any time after puberty.

\section{Puberty Rites of Boys}

Boys have no definite puberty rituals as girls have but they do undergo intensive applications of hunting and fishing charms. Ant frames, incisions in the skin and the rubbing in of plant juices are part of the youth's training as a hunter and it is about the time of puberty that he begins hunting seriously. Unless he is a competent hunter he cannot acquire a man's status or take a wife. Like the girl, who starts having work charms from the age of about 6 on, a boy will start taking hunting charms before puberty and will go on taking them, on and off, all his life, so long as he is capable of hunting. Whenever he has taken a charm a man has to keep away from women, otherwise the charm will be spoilt. The Akawaio say that any charm (murang) can make a girl love you but if you allow it to attract women in this way, then it will not attract meat.

Just as the girl at puberty and women at other times have to use bitter medicines and avoid sweet things which cause a flow of blood, so boys and men, to be successful, have to avoid sweet things which take away their hunting skill. For example, sweet things are be said to cause blood to flow and menstrual blood has something of the essence of sweetness. Hence it 'cools' poison, 


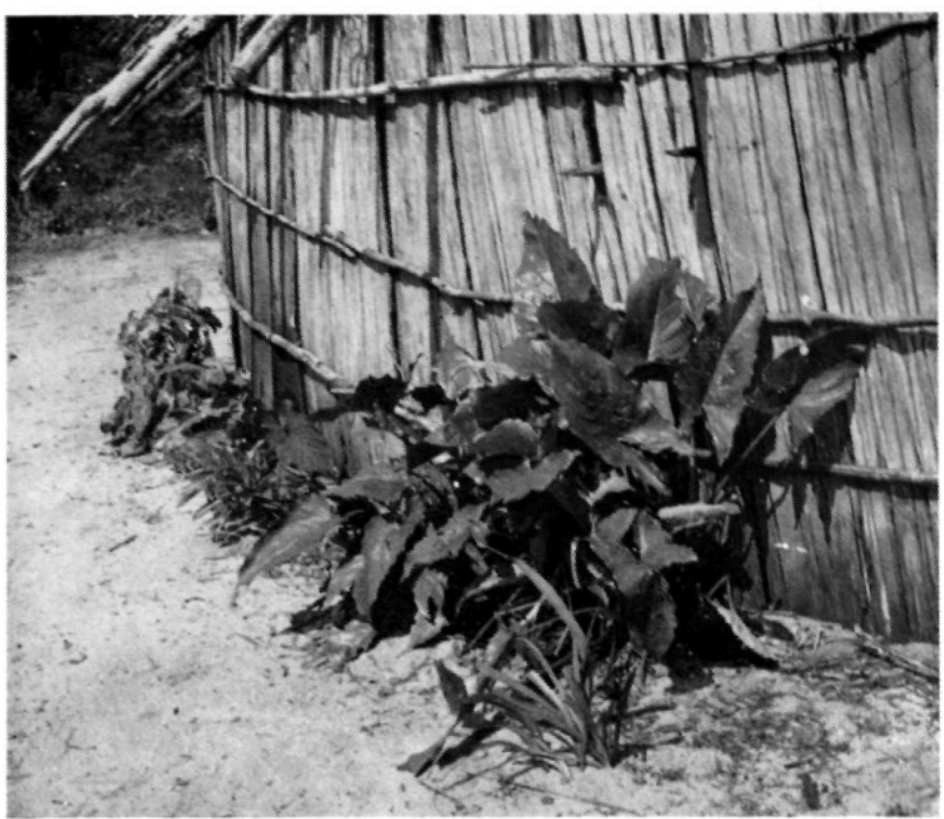

Fig. 3. Hunting Charm plants growing outside an Akawaio dwelling: The Caladium in the foreground is a deer charm - the white spots on the leaf resembling the white spots on the deer's skin. Meruwanking: Kamarang River: Sept. I95I

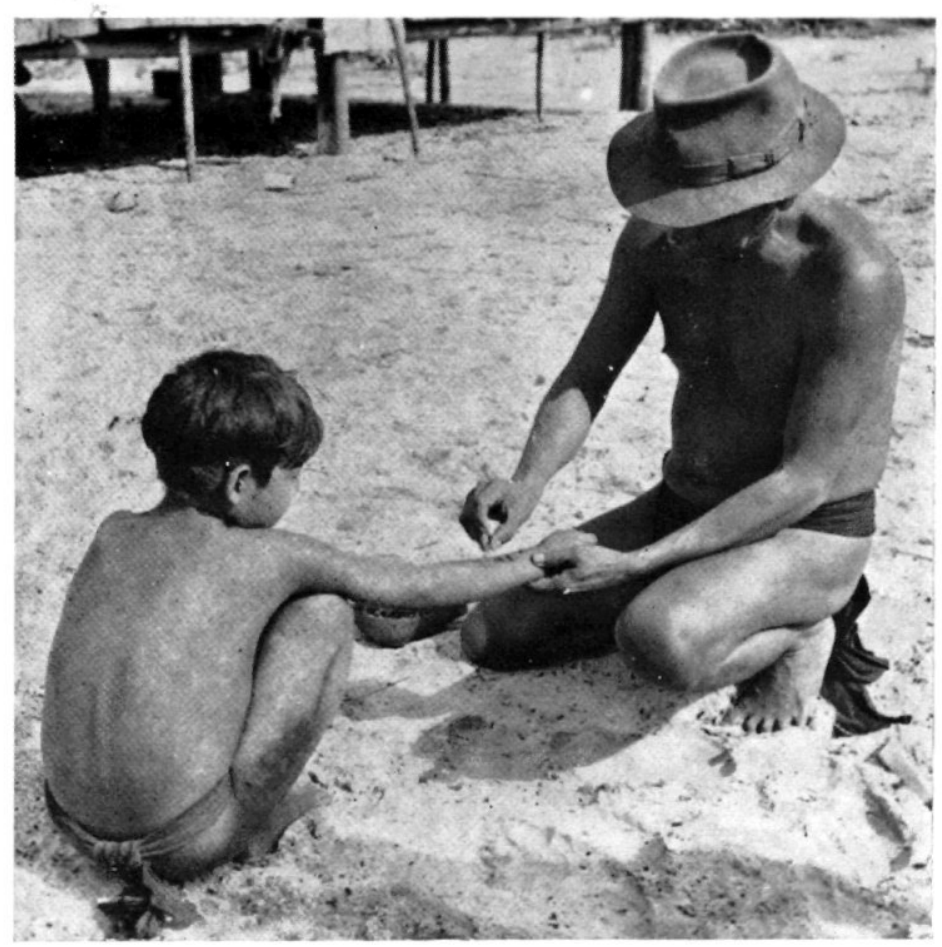

Fig. 4. An Akawaio father giving his son his first hunting charm: The boy's arm is being scratched with a tooth preparatory to rubbing in juice from the root of a charm plant. Shortly after the photograph was taken the father completed the operation by stamping the ground with his foot and making a snorting noise - after the manner of deer. The entire charm was for deer hunting. [Kataima village: Mazaruni River: February 1952] 


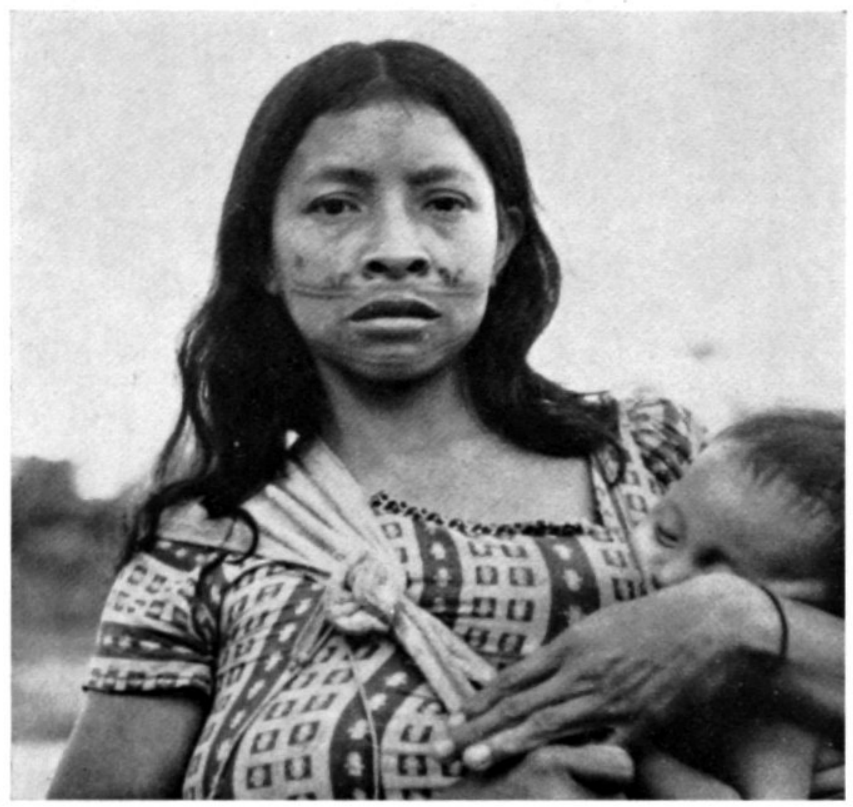

Fig. 5. Scorpion's tail pattern tattooed on chin and along upper lip and cheeks. Fxtra 'hooks' have been added to make a more elaborate pattern. [Pilipai: Kukui River: June 1957.

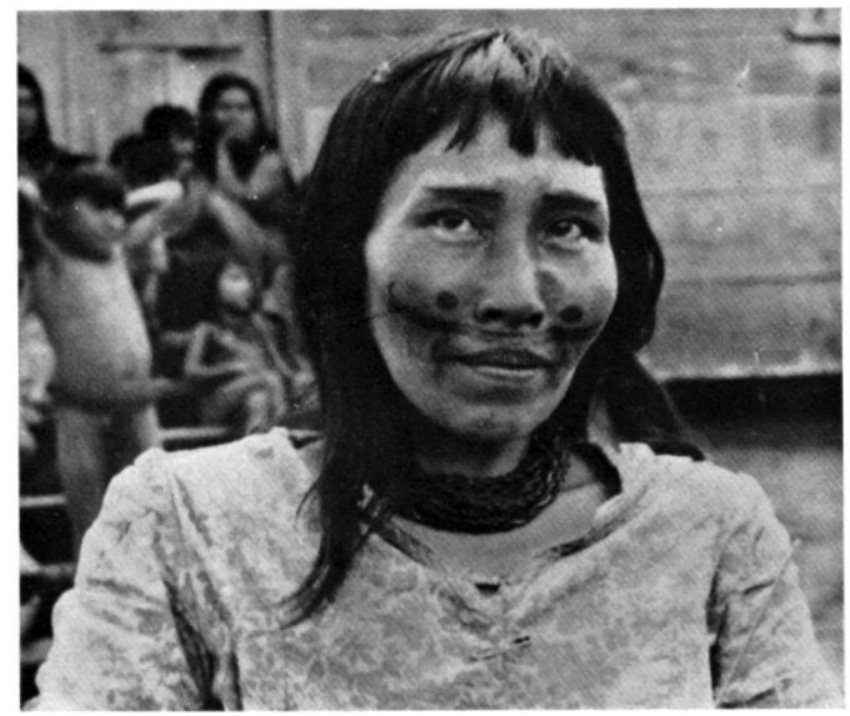

Fig. 6. Akawaio woman's face tattoo pattern which is a cooking and brewing charm. The hooks on the cheeks are the kansök pattern representing the scorpion's tail. (Dots of red paint above the tattooing are for decoration purposes only.) [Kamarang station: Mazaruni District: July r952] 


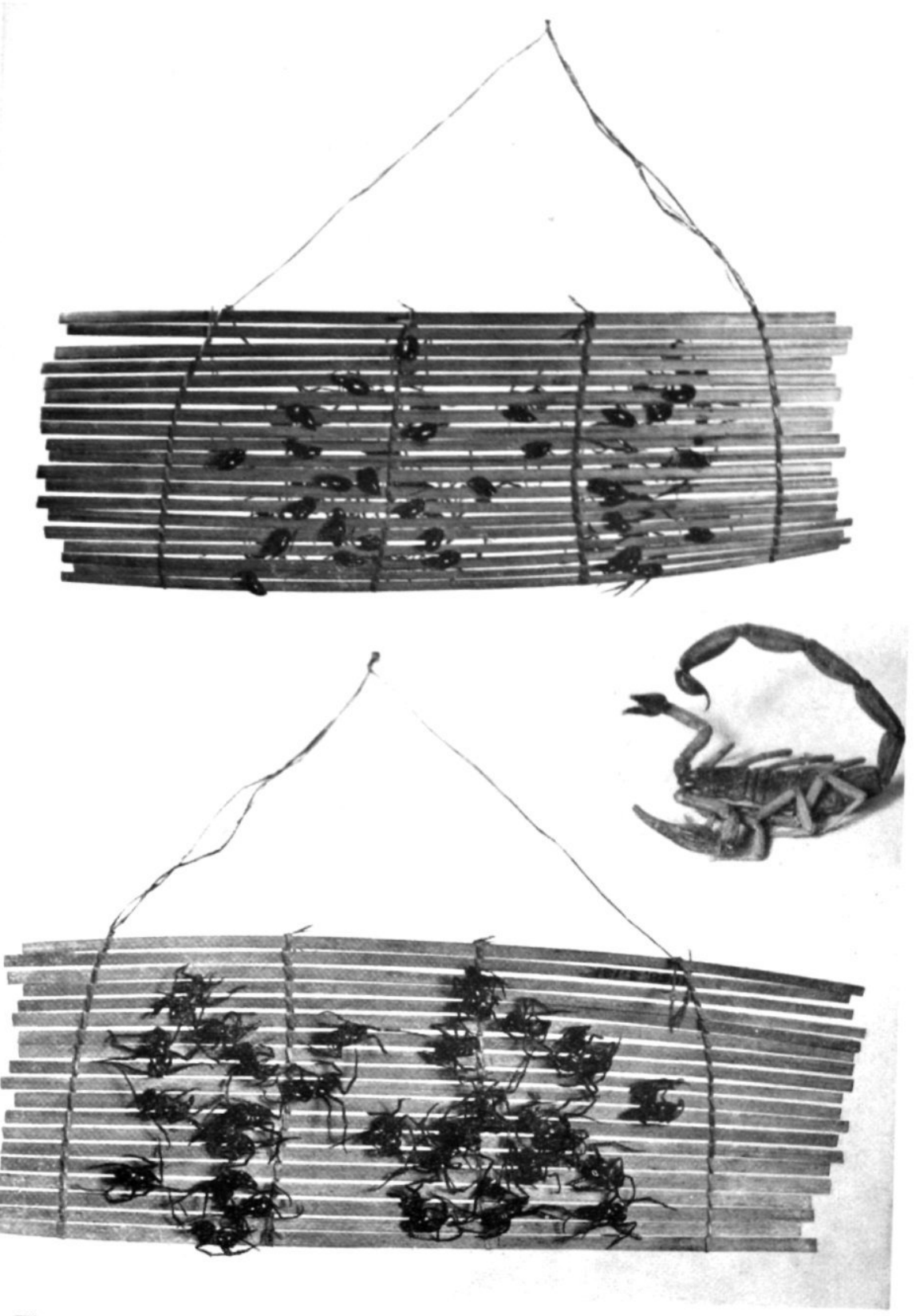

Fig. 7. Rear view of ant frame: showing how the ants are sandwiched between a latticework. [Pitt Rivers Museum] (top)

Fig. 8. Front view of ant frame: These ants get up early in the morning and go out hunting and get much meat - so will the hunter who is stung

Fig.

1.19. 9. A South American scorpion: showing the hooked tail which the kansök tattoo pattern represents. Centrurus gracilis Latr.: in Hope Dept. collection, University Museum, Oxford] (centre) Photographs 7-9 by K. Walters: 1960. 
such as urali (curare) which is used in hunting. Therefore bows and arrows and urali poison have to be removed from any possible contact and menstruating women should not eat with men. The cooling properties of blood are referred to in some blowing words (taling) in which the same name is used for medicine with cooling properties as for menstrual blood. The medicine does not consist of the latter but the association is made in the name, I was told, because of the qualities of coldness held in common.

Sexual relations come into the sweet category - if certain bawdy remarks by a Piait'ma moutain spirit, brought down in a shaman's seance, are to be trusted. This is the reason why the hunter should avoid women at the time of taking a charm.

This division into sweet and bitter and the necessity of using the substance with the appropriate essences, and avoiding the opposite, is also made plain by various food prohibitions which Akawaio observe on particular occasions. For example, during menstruation, and at puberty in particular, women must not eat sweet things so that bananas, pineapples etc., are forbidden. Nor must they eat meat or fish, seemingly because blood and meat ought to be kept strictly apart. During the couvade similar prohibitions are in force for both men and women, for similar reasons, although beliefs relating to spirits also enter into this practice.

Men must not eat sweet things after taking hunting charms until they have been hunting. "If you take sweet things and salt and you fire the gun the meat tastes the sweetness and cannot die".

Curare makers ${ }^{1}$ must not eat sweet things when making the poison otherwise the curare will not kill for the bitterness will be taken away. They can eat only kasarip (the boiled prussic acid from bitter cassava which makes a sauce), cassava bread and pepper. It is interesting to note that among the Makusi tribe to the South, who are almost identical with the Akawaio and who were famous for their poison, the poison maker could not be approached by a pregnant or menstruating woman and could not touch sugar cane or salt. Salt is said to be sweet.

The antidote for snake-bite, the bite of ants or spiders is frequently sugar or salt rubbed into the wound and the early travellers were told that salt or sugar rubbed into a wound made by a curare-coated arrow or dart would make a cure. Scientists

1 To make this famous South American poison a plant of a Strychnos sp. is used - amongst other 'bitter', 'hot', and 'poisonous' ingredients. 
tried these out in experimentation on the poison and found them useless - naturally so, because the Amerindians were thinking along other lines.

Symbolism in Akawaio cures is more complex than in other activities and this is partly due to the spirit element which enters into some types of cure. There is the cure of sickness by blowing words and the symbolism depicted in these. There is cure by the shaman's consultation of the spirits, in which everything occurs at an invisible, spirit, level. Finally, there is cure by the herbal and other nature remedies. The symbolism of these remedies is often related to the characteristics of nature spirits (as Piait'ma and the cooling medicine she has), so that an understanding of both is required. Since Akawaio spirit beliefs are most varied and embrace the whole of their experience in one way or another the anthropologist has to acquire a great deal of knowledge in order to understand the mode of thought which determines the use of certain medicines on certain, specific, occasions.

Added to all this is the further complexity of the Akawaio conception of the qualities of certain substances; some things cool down; some things have the essence of bitterness; some have the essence of sweetness. These classifications are not always obvious to the anthropologist's way of thinking, as in the case of blood and salt which are considered to be sweet.

It is this classification of substances according to certain qualities which they possess, or are thought to possess, which determines the Akawaio use of medicines and the nature of many of the food prohibitions which accompany such ritual occasions as puberty ceremonies and the couvade. Their conceptions are sometimes reminiscent of those of the mediaeval alchemists of Europe and their study of elements and humours. Probably some attempt at classifying and ordering certain elements in their surroundings is a common feature of all societies. The premises and methodology will decide whether the result is a system based on apparent or symbolic resemblances and associations, as among the Akawaio, or on comparative analysis, measurement and experiment, as in a society priding itself on its science.

\section{SUMMARY}

I have used the word 'symbolism' to describe the following:

I) The association between the picture or thought called to mind in Akawaio blowing words (taling) and the social reality 
which the word picture or thought is believed to affect owing to the qualities of resemblance between the two. In addition, I noted that spirit activity is often associated with the affective relationship created by symbolic resemblance.

2) Then I used the word symbolism to describe the association which the Akawaio believe they can create by representing on their faces the creatures whose essential characteristics they wish to emulate in cooking and brewing.

3) I have taken to be symbolic the relationship which is believed to exist between hunting charms and the animals hunted, in fact, between any charm and its object, which is based on the fact of some similarity between the two and so creates an affective relationship.

4) Next, I described charm medicines in which plants, earth, ants etc., have certain major qualities or attributes, such as coldness to take away heat or energy to counteract laziness. In pursuance of this conception of opposites, of cold and heat, bitter and sweet, I discussed observances connected with poison-making and prohibitions on eating certain foods at times of puberty, menstruation, taking charms and during illness.

This conception of medicines, poisons and the essential qualities of substances seems to be merely another facet of the symbolism found in blowing, tattooing and hunting charms. In a sense, it is a negative form of symbolism. A positive form of symbolism involves an association in fact or thought, or through analagous qualities, so that some type of affective relationship is obtained in specific circumstances and some end is thereby achieved. A negative form of symbolism does the opposite and involves a disassociation. It achieves its effect either by keeping apart certain qualities, which particular substances symbolise (food prohibitions are a good example); or, in order to achieve a change of state, the opposite is brought into contact with what predominates. Thus, sweet prevails over bitter or bitter over sweet; the hot prevails over cold or the cold over hot - according to what is required in particular circumstances or according to the state in which a person is conceived to be.

These two different facets of symbolism, which I have called positive and negative symbolism for convenience of reference, are not necessarily found separated in any one set of circumstances, either from each other or from spirit beliefs which appear to stem from a different pattern of thought and from different premises. All are found in Akawaio medical practice and a sick 
person may take advantage of some or all. For example, an Akawaio may get the shaman to summon spirits on his behalf and obtain a spirit cure. The spirits in turn may advise or use a cure involving a symbolic relationship. Piait'ma may dance with the sickness spirit to punish it and so make the patient well by purely spirit activity; on the other hand Piait'ma may bring a cooling medicine, so making the patient well by the use of symbolism from the spirit world. In addition to shaman help the patient may get a friend to blow to achieve a cure - so involving spirit help combined with a positive symbolism. Further, the sick person may try and help himself by taking certain remedies, such as gunpowder to shoot the sickness, or a plant with some aspect which suggests its efficacy. Again, the patient might use a medicine to counteract or annihilate the heat of the illness so employing a remedy based on negative symbolism. Finally, and invariably if the illness is at all serious, certain food restrictions are observed so that certain substances and the qualities they symbolise are kept apart. In recent times the long list of possible attempts at obtaining a cure has been added to by taking whatever the visiting dispenser or anthropologist has to offer in the way of medical aids.

The Akawaio appear to consider that all the modes of thought in which symbolism is involved are essentially in the same category. This is suggested by the fact that the word murang can be used for any sort of charm or medicine, whether these involve either a positive or a negative form of symbolism. They also recognize that modes of thought involving symbolism and those concerning spirit activity, although the two necessarily overlap at times, are essentially different. The way a charm works is not exactly the same way that a spirit works, my informants maintained, even though they state that a charm has a spirit - as indeed everything has. "A charm has a sort of people in it - yet not really people", was all they could say in explanation. Apart from possessing a type of vitality, which is not spirit vitality, they could not say how it worked. They could only point to those aspects of the charm which related it to the thing it could affect or they could state its essential qualities. Perhaps the language barrier was too great for me to understand more, or perhaps I had asked an impossible question.

Symbolism and ritual are obviously closely related among the Akawaio but not in all circumstances. When an Akawaio drinks some clay and water and gets into his hammock to 'cool down' 
his sickness the circumstances are not substantially different from our taking an aspirin and retiring to bed. Neither act is worth dignifying by the name of ritual. It therefore follows that the modes of thought which involve symbolism also extend into every day activities of various kinds and do not only pervade ritual activity. It is a way of thinking which is not confined to any special sphere of life, though it may appear more striking in some social contexts than in others.

\section{REFERENCES}

1 A. J. Burr. "Ritual Blowing" (Taling - A Causation and Cure of Illness among the Akawaio.) Man, Vol. LVI, r956, article 48.

2 J. Gillin. "The Barama River Caribs of British Guiana", p. zo. Papers of the Peabody Museum of American Archaeology \& Ethnology, Vol. XIV, No. 2, 1936.

3 A. J. Butr. "The Mazaruni Scorpion" (A Study of the symbolic significance of Tattoo Patterns among the Akawaio). Timehri, No. 36, Oct. 1957. 